\title{
PENGARUH BIODEGRADASI DENGAN TEKNIK PENANAMAN TERHADAP PRODUK LATEKS KARET ALAM BERPENGISI TEPUNG KULIT PISANG YANG DIPUTIHKAN DENGAN HIDROGEN PEROKSIDA
}

\author{
Erick Kamil, Emelya Khoesoema, Hamidah Harahap \\ Departemen Teknik Kimia, Fakultas Teknik, Universitas Sumatera Utara, \\ Jalan Almamater Kampus USU Medan 20155, Indonesia \\ Email: erick.kamil@gmail.com
}

\begin{abstract}
Abstrak
Produk lateks karet alam yang berpengisi tepung kulit pisang yang diputihkan dengan hydrogen peroksida telah diidentifikasi dengan cara penanaman sampel di dalam tanah. Penanaman dilakukan dengan pemupukan dengan pupuk NPK dan tanpa pemupukan. Pengujian dilakukan dengan melakukan perhitungan kehilangan berat. Hasil yang diperoleh menunjukan bahwa produk lateks karet alam dengan pembebanan pengisi tepung kulit pisang yang diputihkan lebih cepat terbiodegradasi dibandingkan produk lateks karet alam yang tidak diberi pengisi. Pemupukan juga mempercepat biodegradasi. Pengujian yang lain adalah dengan uji FTIR (Fourier Transform Infrared Spectroscopy). Hasil uji dari FTIR menunjukan bahwa terjadi perubahan struktur produk lateks karet alam yang menunjukan bahwa lateks karet alam telah terbiodegradasi.
\end{abstract}

Kata kunci: biodegradasi, pemutihan, tepung kulit pisang, lateks karet alam, hidrogen peroksida

\begin{abstract}
Natural rubber latex products filled with bleached banana skin powder were identified by burying samples in soil. Soil burial was carried out by adding NPK fertilizer and without fertilizer. One of the tests which was carried out was weight loss calculation. Weight loss calculation showed that natural rubber latex products filled with bleached banana skin powder biodegraded faster than natural rubber latex products without filler. The addition of fertilizer also contributed to biodegradability of samples. The other test was FTIR (Fourier Transform Infrared Spectroscopy) test. The results of FTIR test showed there were structure changes in natural rubber latex which indicated natural rubber latex had been biodegraded.
\end{abstract}

Keywords: biodegradation, bleaching, banana skin powder, natural rubber latex, hydrogen peroxide

\section{Pendahuluan}

Masalah utama yang perlu diperhatikan dari penggunaan karet adalah limbah produk karet dan pembuangan material karet yang dapat menyebabkan pencemaran lingkungan. Salah satu usaha untuk mengatasi pencemaran lingkungan ini adalah dengan biodegradasi. Biodegradasi memainkan peran penting dalam penanganan limbah produk karet alam. Konstituen utama karet alam adalah cis-1,4-poliisoprena. Karet alam relatif resistan terhadap dekomposisi bakteri. Kendati demikian,telah banyak laporan biodegradasi produk karet alam oleh bakteri seperti bakteri Xanthomonas [1],Pseudomonas aeruginosa[2], dan Bacillus sp. [3].

Pemberian pengisi ada berbagai tujuan yaitu sebagai penguat, dan untuk mengurangi biaya [4]. Anhwange melaporkan bahwa kulit pisang mengandung serat sekitar $31,7 \%$ [6] yang merupakan potensi sumber serat alami untuk digunakan sebagai pengisi. Pemanfaatan tepung kulit pisang sangat memungkinkan untuk menjadi alternatif sebagai pengisi bagi produk lateks karet alam. Selain itu, kulit pisang sangat mudah dijumpai dan merupakan limbah yang di buang. Penggunaan kulit pisang yang merupakan sampah organik dari buah pisang juga bisa mengurangi volume sampah atau limbah yang akan mencemari lingkungan.

Hamidah Harahap et al melaporkan bahwa karet alam berpengisi tepung kulit pisang dapat terbiodegradasi [7].Pemutihan tepung kulit pisang dilakukan karena tepung kulit pisang yang digunakan berwarna hitam sehingga menyebabkan karet alam berpengisitepung kulit pisang berwarna hitam.Tepung kulit pisang yang diputihkan dengan hidrogen peroksida digunakan sebagai pengisi lateks karet alam. Karet alam bisa terbiodegradasi, tetapi jika dibandingkan dengan polimer alam lainnya, karet alam lebih resistan terhadap biodegradasi mikroba pada kondisi ekologi normal [5]. Karena tepung kulit pisang yang diputihkan dan karet alam sama-sama dapat terbiodegradasi, maka komposit yang terbuat dari karet alam berpengisi tepung kulit pisang yang diputihkan diharapkan dapat terbiodegradasi juga.

Teori

Lateks karet alam merupakan cis-1,4poliisoprena, yang dapat disintesa oleh lebih dari 2000 spesies tanaman yang tergolong kepada Euphorbiaceae. Karet alam diproduksi dalam secara besar-besaran (hingga $10^{7}$ ton/tahun) dari pohon karet Hevea brasiliensis. Cis-1,4-poliisoprena merupakan konstituen utama (>90\% berat kering) 
mengandung minimum $90 \%$ hidrokarbon karet dengan sebagian kecil pengotor seperti resin, asam lemak, gula, dan mineral [9]. Pengotor organik dalam karet juga dapat membantu pertumbuhan bakteri [10]. Bakteri Actinomycetes dapat menguraikan karet alam. Mekanisme biodegradasi karet alam oleh bakteri Actinomycetes adalah pemutusan ikatan rangkap pada cis 1,4-poliisoprena oleh oksigen dan menghasilkan gugus karbonil yaitu aldehida dan keton di mana terdapat satu molekul oksigen pada masing-masing sisi [1].

\section{Metodologi Penelitian}

Pengisi yang digunakan adalah kulit pisang yang terlebih dahulu dikeringkan. Kulit pisang yang telah kering dihancurkan dan diayak hingga diperoleh tepung kulit pisang berukuran 100 mesh dan diputihkan dengan larutan hidrogen peroksida pada suhu $80^{\circ} \mathrm{C}$ selama $1 \mathrm{jam}$. Sistem pemutih dibuat dengan mengencerkan larutan hidrogen peroksida $50 \%$ menjadi larutan hidrogen peroksida $6 \%$ dengan penambahan air. $\mathrm{pH}$ larutan dinaikan hingga 11 dengan penambahan larutan natrium hidroksida $10 \%$. Tepung kulit pisang yang telah diputihkan dicuci dengan air dan dibuat menjadi sistem dispersi. Sistem dispersi dibuat dari tepung kulit pisang yang diputihkan, air dan polivinil pirolidon dengan perbandingan berat 15 berbanding 83 berbanding 2 .

Bahan-bahan kuratif dan lateks karet alam amonia tinggi, seperti yang ditampilkan pada Tabel 1, di-pra-vulkanisasi pada suhu $70{ }^{\circ} \mathrm{C}$ selama 15 menit. Lateks karet alam pra-vulkanisasi dicampur dengan sistem dispersi pengisi dan diaduk. Persenyawaan lateks divulkanisasi pada suhu 100 ${ }^{\circ} \mathrm{C}$ selama 15 menit, dengan teknik pencelupan menggunakan pembentuk. Pembentuk yang digunakan berupa pelat tipis yang dicelupkan ke dalam persenyawaan karet.

Untuk proses biodegradasi, produk lateks karet alam berpengisi tepung kulit pisang yang telah diputihkan dengan hidrogen peroksida ditimbang dan dicatat massa dari setiap sampel yang akan diuji. Kemudian sampel tersebut ditanam dengan kedalaman $20 \mathrm{~cm}$ dari permukaan tanah, dan dilakukan variasi pada tanah dimana ada tanah yang diberikan pupuk dan ada yang tidak menggunakan pupuk. Proses penanaman dan penggantungan sampel dilakukan dari 1 hingga 16 minggu.
Tabel 1. Bahan-bahan senyawaan latex pravulkanisasi

\begin{tabular}{lc}
\hline \multicolumn{1}{c}{ Bahan } & Berat basah (gr) \\
\hline High Ammonia Lateks & 166,67 \\
Larutan Sulfur 50\% & 3 \\
Larutan ZDEC ${ }^{\dagger} 50 \%$ & 3 \\
Larutan ZnO 30\% & 0,83 \\
Larutan Antioksidan 50\% & 2 \\
Larutan KOH 10\% & 3 \\
Pengisi (tepung kulit pisang) & $0,5,10,15,20,25$ \\
\hline
\end{tabular}

$\dagger$ ZDEC: Zinc Diethylditiocarbamate

\section{Hasil}

Pada penanaman dengan pupuk, dapat dilihat dari Gambar 1 bahwa persentase kehilangan berat yang paling besar adalah karet alam dengan pembebanan pengisi 10 bsk, yaitu 40,4692\%. Persentase kehilangan berat yang paling sedikit adalah lateks karet alam yang tidak berpengisi yaitu $27,2966 \%$. Persentase kehilangan berat karet alam dengan pembebanan pengisi 5 bsk; 15 bsk; dan 20 bsk masing-masing adalah 35,5903\%; 39,0947\%; dan $38,0451 \%$.

Dari Gambar 1 secara keseluruhan, karet alam dengan pembebanan pengisi 10 bsk memiliki persentase kehilangan berat yang paling besar. Sedangkan karet alam yang tidak berpengisi memiliki kehilangan berat yang paling kecil. Penambahan beban pengisi 5 bsk meningkatkan laju biodegradasi dibandingkan dengan pembebanan pengisi 0 bsk. Penambahan beban pengisi hingga 10 bsk juga meningkatkan laju biodegradasi, hal ini karena produk lateks karet alam tahan terhadap serangan mikroba [8]. Peningkatan beban pengisi lebih lanjut yaitu 15 bsk; dan 20 bsk justru mengurangi laju biodegradasi produk lateks karet alam. Hal ini disebabkan Pengisi yang digunakan adalah tepung kulit pisang yang telah diputihkan dengan hydrogen peroksida dengan ukuran 100 mesh. Tepung kulit pisang mudah berinteraksi dengan sesamanya sehingga ketika dilakukan penambahan pembebanan pengisi, tepung kulit pisang akan mengalami aglomerasi membentuk partikel yang berukuran lebih besar, sehingga memperkecil luas permukaan untuk pertumbuhan mikroba, sehingga biodegradasi akan menurun. 


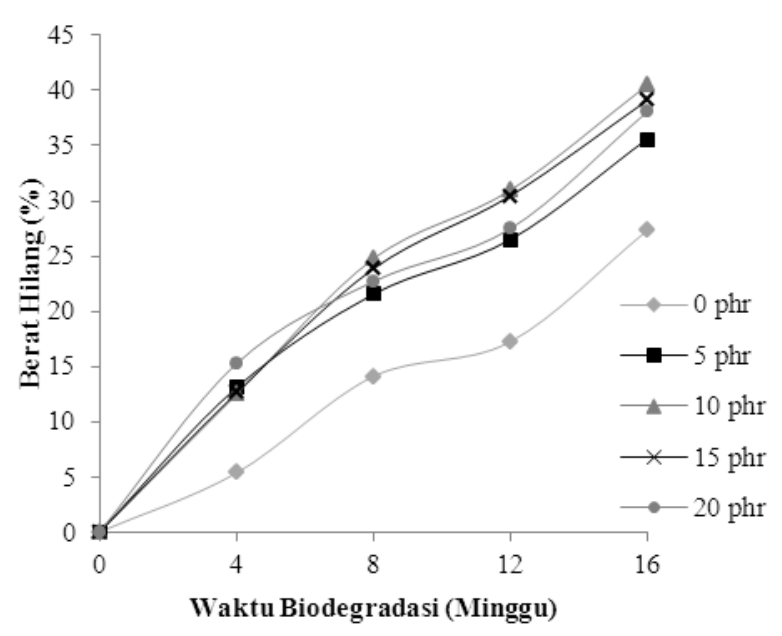

Gambar 1. Pengaruh pembebanan pengisi terhadap biodegradasi produk lateks karet alam dengan penanaman dengan pemupukan

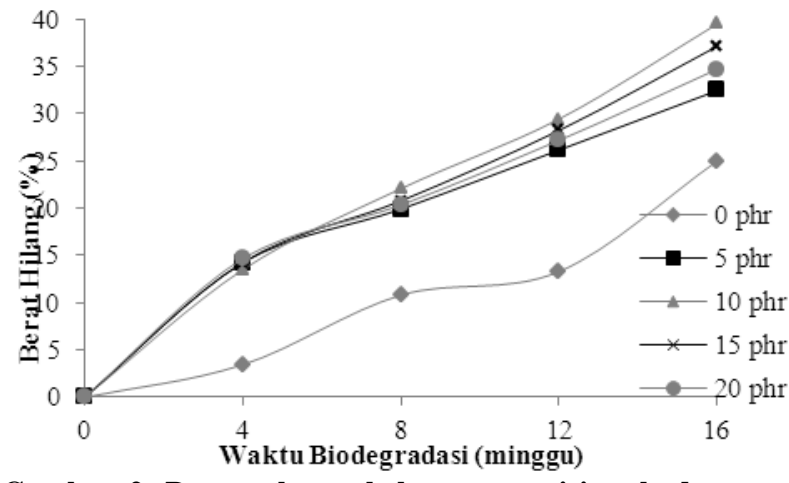

Gambar 2. Pengaruh pembebanan pengisi terhadap biodegradasi produk lateks karet alam dengan penanaman tanpa pemupukan

Pada penanaman tanpa pupuk, dapat dilihat dari Gambar 2 bahwa persentase kehilangan berat yang paling besar adalah karet alam dengan pembebanan pengisi 10 bsk, yaitu 39,5028\%. Persentase kehilangan berat yang paling sedikit adalah lateks karet alam yang tidak berpengisi yaitu 25,000\%. Persentase kehilangan berat karet alam dengan pembebanan pengisi 5 bsk; 15 bsk; dan 20 bsk masing-masing adalah 32,4561\%; 37,1324\%; dan $34,7122 \%$.

Dari Gambar 2 karet alam tanpa pengisi menunjukan kehilangan berat yang paling kecil dibandingkan dengan karet alam dengan pembebanan pengisi. Secara keseluruhan, karet alam dengan pembebanan pengisi 10 bsk memiliki persentase kehilangan berat yang paling besar. Penambahan beban pengisi 5 bsk meningkatkan laju biodegradasi dibandingkan dengan pembebanan pengisi 0 bsk. Penambahan beban pengisi hingga 10 bsk juga meningkatkan laju biodegradasi, hal ini karena produk lateks karet alam tahan terhadap serangan mikroba [8]. Pada penanaman tanpa pupuk, hal yang sama juga dapat diperhatikan dari kehilangan berat sampel yaitu apabila beban pengisi ditingkatkan lebih lanjut yaitu hingga 15 bsk; dan 20 bsk, hal tersebut justru mengurangi laju biodegradasi produk lateks karet alam. Hal ini disebabkan pengisi tepung kulit pisang yang telah diputihkan dengan hidrogen peroksida dengan ukuran 100 mesh mudah berinteraksi dengan sesamanya dan ini akan mengalami aglomerasi membentuk partikel yang berukuran besar sehingga memperkecil luas permukaann pertumbuhan mikroba sehingga biodegradasi akan menurun.

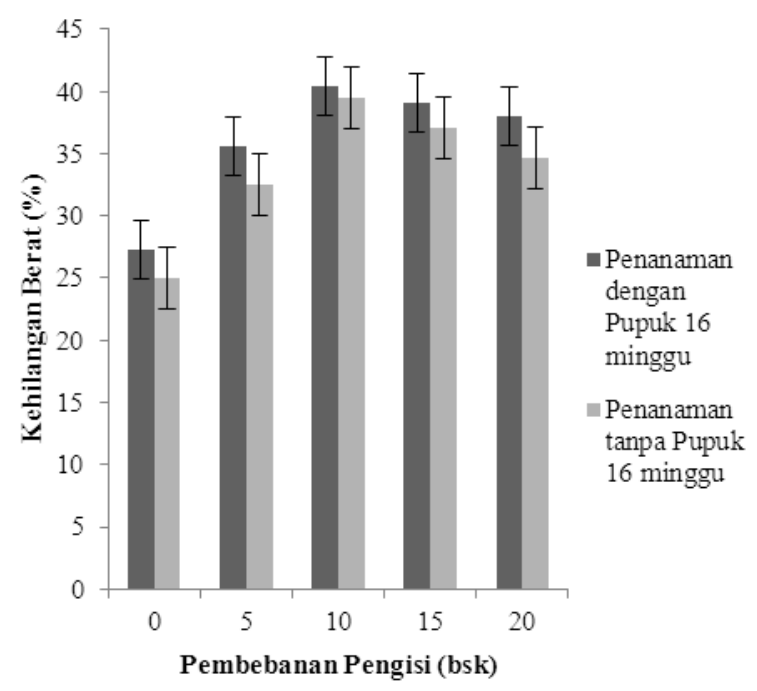

Gambar 3. Perbandingan Kehilangan Massa Produk Lateks Karet Alam Dengan dan Tanpa Pemupukan dengan Variasi Pembebanan

Laju dan lama biodegradasi karet alam dipengaruhi oleh kandungan pengisinya, mikroba dan interaksi dengan lingkungan [3]. Berdasarkan proses kehilangan berat pada Gambar 3, produk yang terbiodegradasi terjadi lebih baik pada produk yang dibiodegradsi dengan penanaman menggunakan pemupukan. Secara keseluruhan pada grafik menunjukkan bahwa proses penanaman tanpa menggunakan pupuk mengalami laju biodegradasi yang lebih lambat dibanding yang dibiodegradasi dengan penanaman menggunakan pupuk. 


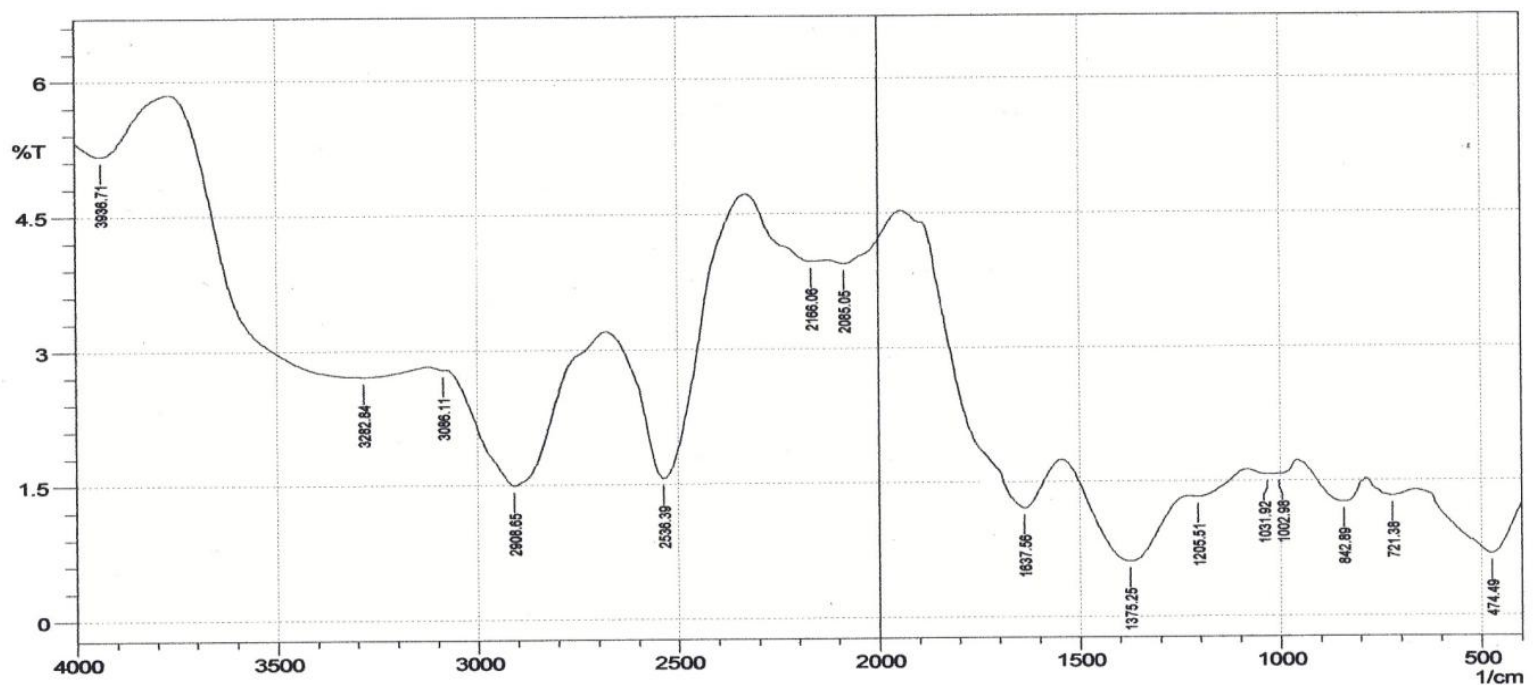

(a)

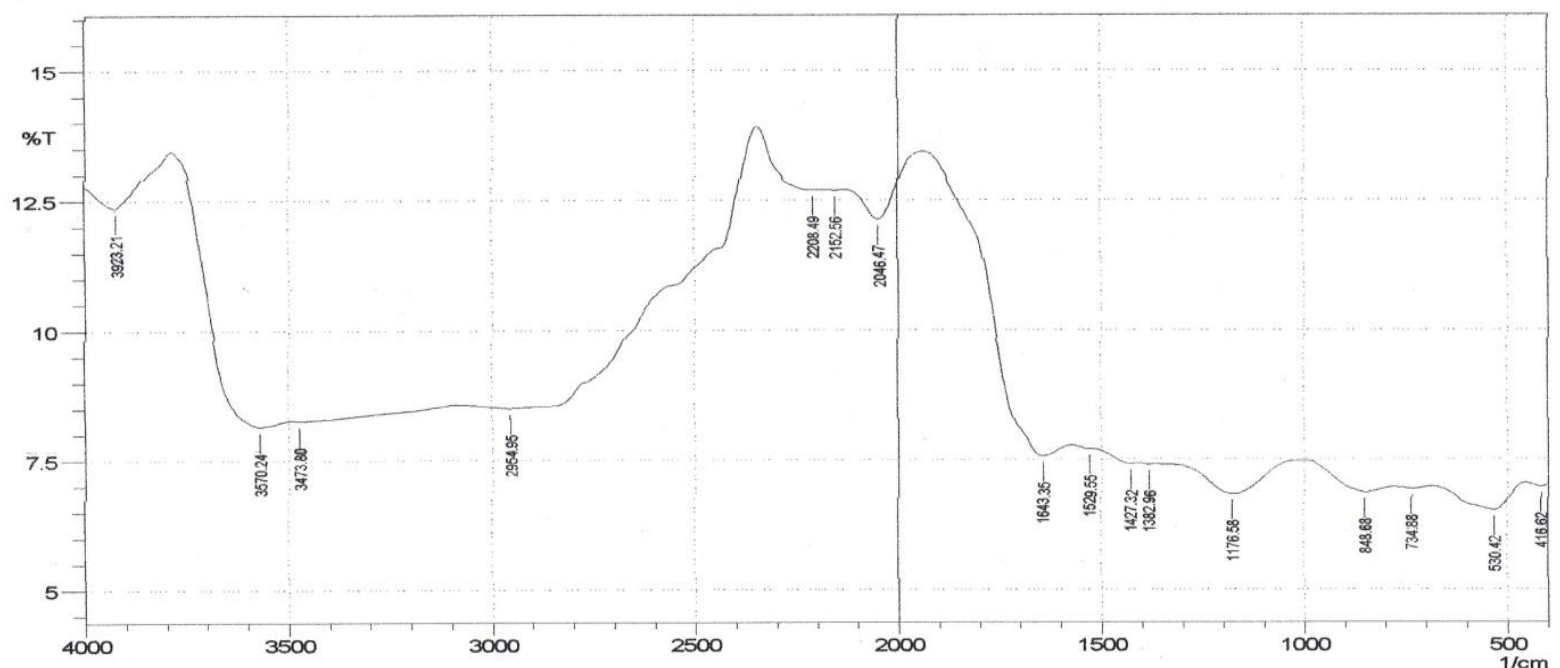

(b)

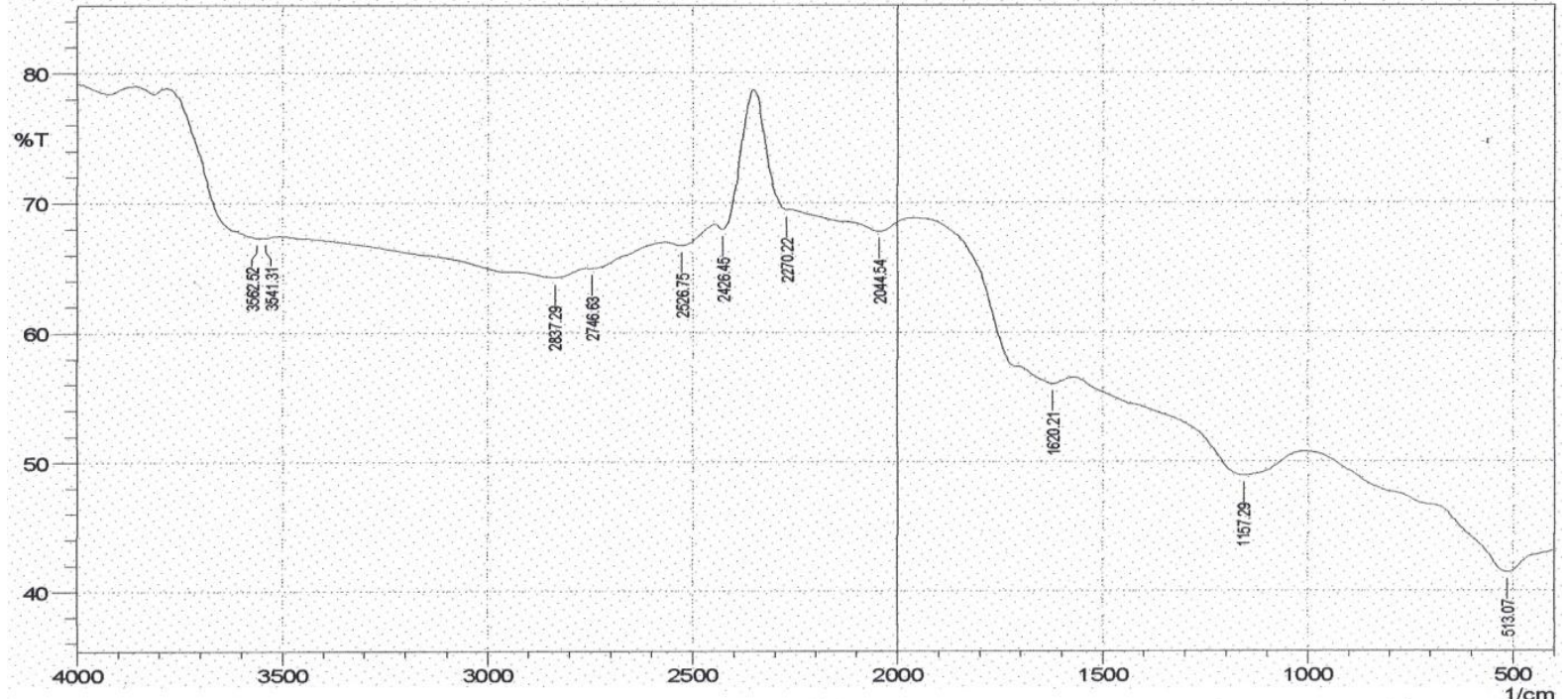

(c)

Gambar 4. Spektrum FTIR dari Produk Lateks Karet Alam Berpengisi Tepung Kulit Pisang yang Diputihkan dengan Hidrogen Peroksida 20 bsk Sebelum Penanaman (a) dan Penanaman dengan Pupuk (b), dan Penanaman Tanpa Pupuk (c) 
Gambar 4(a) menunjukan spektra FTIR karet alam berpengisi tepung kulit pisang yang diputihkan sebelum ditanam. Hasil uji FTIR sampe yang telah ditanam ditampilkan pada Gambar 4 (b) dan 4 (c). Dapat dilihat pada Gambar 4 bahwa ada kemunculan dan kehilangan dari beberapa puncak pada spektrum FTIR. Pada Gambar 4(a) terdapat puncak 2908,65 $\mathrm{cm}^{-1}$ yang merupakan gugus alkana $\left(\mathrm{CH}_{3}\right)$, sedangkan pada Gambar 4(b) terdapat puncak 2954,95 $\mathrm{cm}^{-1}$ yang juga merupakan gugus alkana $\left(\mathrm{CH}_{3}\right)$. Sebelum penggantungan, gugus alkana menunjukan puncak yang tajam, sementara sesudah penggantungan, puncak menjadi datar dan kehilangan intensitas. Gugus polisakarida pada puncak 1031,92 $\mathrm{cm}^{-1}$ dan $1002,98 \mathrm{~cm}^{-1}$ pada sampel sebelum penanaman juga hilang. Setelah penanaman, muncul puncak yang lebar $3570,24 \mathrm{~cm}^{-}$ ${ }^{1}$ (b), dan $3562,52 \mathrm{~cm}^{-1}$ dan $3541,31 \mathrm{~cm}^{-1}$ (c) yang merupakan gugus hidroksil $(\mathrm{O}-\mathrm{H})$ yang menandakan bahwa mikroba telah menembus matriks karet dan menguraikan polisakarida menjadi alkohol. Pada Gambar 4(c) terdapat puncak $2873,29 \mathrm{~cm}^{-1}$ dan $2746,63 \mathrm{~cm}^{-1}$ yang merupakan gugus aldehida (C-H). Puncak 1176,58 $\mathrm{cm}^{-1}(\mathrm{~b})$ dan $1157,29 \mathrm{~cm}^{-1}$ (c) yang merupakan gugus keton (C-C) sebelumnya tidak ada pada Gambar 4(a) juga muncul yang menandakan bahwa cis-1,4poliisoprena karet alam telah diurai oleh mikroba menjadi aldehida dan keton [1].

\section{Kesimpulan}

Penambahan pembebanan tepung kulit pisang yang diputihkan akan meningkatkan kemampuan biodegradasi produk lateks karet alam. Pembebanan pengisi 10 bsk adalah pembebanan dengan sifat biodegradasi yang paling bagus, sementara pembebanan pengisi lebih lanjut malah menurunkan kemampuan biodegradasi. Proses biodegradasi produk yang ditanam dengan pemupukan lebih cepat dibanding produk yang tanpa pemupukan. Hasil FTIR menunjukan bahwa cis-1,4-poliisoprena berhasil digunakan sebagai sumber karbon dan diuraikan oleh mikroba.

\section{Daftar Pustaka}

[1] A. Tsuchii, T. Suzuki, dan K. Takeda. Appl. Environ. Microb. 50 (4), pp.965 - 970, 1985.

[2] A. Linos, M.M. Berekaa, R. Reichelt, U. Keller, J. Schmitt, H. C. Fleming, R. M. Kroppenstedt, dan A. Steinbuchel. Appl. Environ. Microb. 66 (4), pp.1639-1645, 2000.

[3] E. Cheriandan K. Jayachandran. Int. J. Environ. Res. 3(4), pp.599-604, 2009.

[4] N. Rattanasom, T. Saowapark, dan C. Deeprasertkul. Polym. Test. 26 pp. 369-377, 2006.

[5] K. Rose, dan A. Steinbuchel. Appl. Environ. Microb. 71, p.2803-2812, 2005.

[6] B. A. Anhwange, T. J. Ugye dan T. D. Nyiaatagher. E. J. of Env., Agri., and Food Chem. 8(6), pp.437-442, 2008.

[7] H. Harahap, A. Boy dan N. Sitorus. J. Ilmu Pengetahuan dan Terapan Reintek 6(1), pp.23-30, 2011.

[8] H. M. Rifaat, dan M. A. Yosery. Appl. Eco. Environ. Res. 2(1), pp.63-70. 2004.

[9] B. J. Zyska. Microbial Biodeterioration, Economic Microbiology. Penerbit Academy Press, London. pp.323-385, 1981.

[10] C. E. Zobell, dan J. D. Beckwith. J. Am. Water Work Associat. 36, pp.439-453,1994. 